\title{
UPAYA PENGHAPUSAN KEKERASAN DALAM RUMAH TANGGA (KDRT) MELALUI UNDANG-UNDANG
}

\author{
Nita Yuniarti \\ E-mail: adandalho@gmail.com
}

\begin{abstract}
The general nature of man is basically inclined towards goodness, but this tendency can change due to three factors. First, when you see an opportunity to do bad things. Second, when there is an unbearable basic need. Third, there is desire that is out of control. So controlling the three factors that cause humans to do bad things must be strived for, so that humans always tend to goodness. Law of the Republic of Indonesia Number 23 of 2004 concerning the Elimination of Domestic Violence, and Law of the Republic of Indonesia Number 17 of 2016 concerning Stipulation of Government Regulations in Lieu of Law Number 1 of 2016 concerning the Second Amendment to Law Number 23 of 2002, Concerning Child Protection, is one of the state's efforts to block human opportunities to commit crimes in the form of violence in their household. This paper uses a qualitative approach with descriptive methods. The data collection technique is observation through literature study. The problem in this research is the hope of reducing domestic violence behavior after the enactment of the PKDRT Law, but the facts show different things. The results of the study prove that the graph of domestic violence after the enactment of this law is still increasing.
\end{abstract}

Key words: good character; bad character; domestic violence.

\begin{abstract}
Abstrak
Sifat umum manusia itu pada dasarnya adalah cenderung pada kebaikan, namun kecenderungan itu bisa berubah karena tiga factor. Pertama, ketika melihat ada kesempatan untuk berbuat buruk. Kedua, ketika ada kebutuhan mendasar yang tidak tertahankan. Ketiga, ada keinginan yang tidak terkendali. Maka mengendalikan ketiga factor penyebab manusia untuk berbuat buruk itu harus terus diupayakan, agar manusia selalu cenderung pada kebaikan. Undang-Undang Republik Indonesia Nomor 23 Tahun 2004 Tentang Penghapusan Kekerasan Dalam Rumah Tangga, dan UndangUndang Republik Indonesia Nomor 17 Tahun 2016 Tentang Penetapan Peraturan Pemerintah Pengganti Undang-Undang Nomor 1 Tahun 2016 Tentang Perubahan Kedua Atas Undang-Undang Nomor 23 Tahun 2002, Tentang Perlindungan Anak, adalah salah satu upaya negara untuk menutup kesempatan manusia untuk berbuat jahat berupa kekerasan dalam rumah tangganya. Tulisan ini menggunakan pendekatan kualitatif dengan metode deskriptif. Teknik pengumpulan datanya adalah observasi melalui studi pustaka. Masalah dalam penelitian ini adalah berupa harapan berkurangnya perilaku kekerasan dalam rumah tangga setelah berlakunya Undang-Undang PKDRT, namun fakta yang ada menunjukkan hal yang berbeda. Hasil kajian membuktikan bahwa grafik kekerasan dalam rumah tangga setelah berlakunya undang-undang tersebut masih terus meningkat.
\end{abstract}

Kata kunci: Sifat baik; Sifat buruk; kekerasan dalam rumah tangga.

Manusia sejak awal kelahirannya telah memiliki naluri negative dan naluri postif (Q.S. 91, Asy-Syams; 7-8). Naluri negative manusia itu dibimbing oleh hawa nafsu, sedangkan naluri positif manusia itu dibimbing oleh akal dan pikirannya. Pada umumnya manusia 
lebih suka untuk mengikuti naluri positifnya, karena hal itu lebih mendatangkan kenyamanan dalam hidupnya.

Itulah sebabnya jumlah orang jahat di dunia ini sepertinya lebih sedikit daripada orang baik. Salah satu barometernya adalah penduduk yang berdiam di suatu wilayah, tentu lebih banyak yang hidup normal dalam masyarakatnya, dibanding dengan orang yang hidup dalam penjara.

Namun jika dilihat lebih spesifik lagi, ternyata orang yang hidup di penjara itu adalah orang yang kadar kejahatannya sudah mencapai tingkat tertentu sehingga terjaring atau tertangkap, atau karena ada yang melaporkan. Jadi masyarakat yang hidup di luar penjara pun, bisa jadi sebenarnya sudah berbuat jahat, atau berbuat buruk, tapi belum mencapai derajat tertentu, atau bisa jadi karena belum ada yang melaporkannya.

Jahat itu artinya menyakiti dan atau merugikan pihak lain, misalnya menghina, memukul, mencuri, dan lainnya, sedangkan buruk itu artinya menyakiti dan atau merugikan diri sendiri, misalnya berjudi, merokok, minum beralkohol, dan sebagainya.

Ada banyak bentuk kejahatan yang harus diwaspadai, termasuk kejahatan yang dapat dilakukan oleh orang terdekat kita. Kejahatan semacam itu terpendam dan sering tidak terekspos, misalnya berupa perilaku kekerasan dalam rumah tangga / KDRT.

$$
\text { perilaku kekerasan dalam }
$$
rumah tangga ini banyak terjadi di Indonesia. Sehingga akhirnya pemerintah dan pi-hak legislative memandang perlu untuk membuat peraturan yang dapat meng-hapus, atau setidaknya mengurangi, atau mengendalikan perilaku kekerasan dalam rumah tangga. Yaitu UndangUndang Nomor 23 tahun 2004 Tentang Penghapusan Kekerasan dalam Rumah Tangga, dan Undang-Undang Republik Indonesia Nomor 17 Tahun 2016 Tentang Penetapan Peraturan Pemerintah Pengganti Undang-Undang Nomor 1 Tahun 2016 Tentang Perubahan Kedua Atas Undang-Undang Nomor 23 Tahun 2002, Tentang Perlindungan Anak.

Undang-Undang sebagaimana tersebut memiliki hubungan dengan undang-undang lainnya yang sudah berlaku (Jogloabang; Oktober 2020) yaitu:

1. Undang-undang Nomor 1 Tahun 1946 tentang Kitab Undang-Undang Hukum Pidana serta Perubahannya.

2. Undang-Undang Nomor 8 Tahun 1981 tentang Kitab Undang-undang Hukum Acara Pidana.

3. Undang-undang Nomor 1 Tahun 1974 tentang Perkawinan.

4. Undang-undang Nomor 7 Tahun 1984 tentang Pengesahan Konvensi mengenai Penghapusan Segala Bentuk Diskriminasi Terhadap Wanita (Convention on the Elimination of All Forms of Discrimination Against Women).

5. Undang-Undang Nomor 39 Tahun 1999 tentang Hak Asasi Manusia.

Data Survei Pengalaman Hidup Perempuan Nasional (SPHPN) Tahun 2016 menunjukkan bahwa 1 dari 3 perempuan (atau 10 dari 30 orang perempuan) mengalami kekerasan fisik dan seksual, serta 6 dari 10 (atau 60 dari 100 orang) perempuan mengalami KDRT lainnya.

Ada banyak faktor yang melatar-belakangi terjadinya KDRT, diantara-nya adalah rendahnya tingkat pendi-dikan, ekonomi, perselingkuhan, 
pere-butan hak pengasuhan, balas dendam, penyalahgunaan narkoba / miras, per-bedaan karakter budaya, dan kurang-nya persiapan pasangan sebelum meni-kah, baik dari sisi fisik, mental, maupun psikologis sehingga pondasi rumah tangga ketika terjadi permasalahan mudah goyah (Kemenpora 1; Oktober 2020).

Kekerasan Dalam Rumah Tangga / KDRT pada masa kini bukanlah merupakan persoalan personal yang menjadi rahasia pribadi, dan yang tidak boleh diketahui orang lain. KDRT adalah pelanggaran Hak Asasi Manusia (HAM) dan kejahatan terhadap nilai kemanusiaan, serta bentuk intimidasi yang harus dihapuskan. Untuk itu, UU PKDRT / Penghapusan Kekerasan Dalam Rumah Tangga merupakan jaminan yang diberikan oleh negara untuk mencegah terjadinya KDRT, menindak pelaku, dan melindungi korban (Kemenpora 2; Oktober 2020).

Pemerintah melalui Kementerian Pemberdayaan Perempuan dan Perlindungan Anak (Kemen- PPPA) dan pihak legislative bersepakat untuk mengeluarkan Undang-Undang Nomor 23 Tahun 2004 tentang Penghapusan Kekerasan Dalam Rumah Tangga dan Peraturan Pemerintah No. 4 tahun 2006 tentang Penyelenggaraan dan Kerja-sama Pemulihan Korban Kekerasan Da-lam Rumah Tangga, guna menyikapi maraknya fenomena KDRT yang terjadi di masyarakat.

Pemerintah menilai setiap warga negara berhak mendapatkan rasa aman dan lepas dari segala bentuk kekerasan. Selain itu, korban kekerasan dalam rumah tangga, yang kebanyakan adalah perempuan, harus mendapat perlin-dungan dari negara dan atau masya-rakat agar terhindar dan terbebas dari kekerasan atau ancaman kekerasan, penyiksaan, atau perlakuan yang merendahkan derajat dan martabat kemanusiaan. Kondisi ini menunjukkan bahwa negara ingin melindungi seluruh rakyatnya, terutama kaum perempuan dan anakanak.

Untuk perlindungan anak, pihak negara juga sudah berusaha maksimal untuk menjaganya sebagaimana tertuang dalam Undang-Undang Republik Indonesia Nomor 35 Tahun 2014 Tentang Perubahan Atas Undang-Undang Republik Indonesia Nomor 23 Tahun 2002 Tentang Perlindungan Anak, dan Peraturan Pemerintah Nomor 59 Tahun 2019 tentang Penyelenggaraan Koordinasi Perlindungan Anak.

Kehidupan berumah tangga idealnya adalah saling menjaga dan melindungi antara satu dengan lainya, namun fakta yang terjadi menunjukkan bahwa tingkat perilaku kekerasan dalam rumah tangga cukup tinggi. Sehingga dalam hal ini, pihak penyelenggara negara memandang perlu untuk menjaga dan melindungi korban dan atau calon korban perilaku kekerasan tersebut.

Masalah dalam penelitian ini adalah harapan berkurangnya perilaku kekerasan dalam rumah tangga setelah berlakunya Undang-Undang PKDRT, namun fakta yang ada menun-jukkan hal yang berbeda. Rumusan masalahnya adalah: Bagaimanakah grafik perilaku kekerasan yang terjadi dalam rumah tangga di Indonesia pasca diberlakukannya undang-undang tersebut?

Tujuan penulisan ini adalah untuk mendeskripsikan perilaku kekerasan yang terjadi dalam rumah tangga 
di Indonesia pasca dikeluarkannya undang-undang tersebut.

\section{METODE PENELITIAN}

Penyusunan tulisan ini adalah pendekatan kualitatif, metode deskriptif dengan kajian Pustaka dengan teknik pengumpulan datanya adalah observasi melalui pencermatam kepustakaan, dan analisis datanya adalah naratif.

\section{Pembahasan}

Harapan dibuatnya UndangUndang PKDRT adalah untuk menekan dan menurunkan angka perilaku keke-rasan dalam rumah tangga, namun fak-ta yang terjadi di lapangan adalah ma-sih tingginya angka perilaku kekerasan tersebut.

Hasil penelitian menunjukkan bahwa diskrepansi antara harapan dan kenyataan itu masih berbeda. Grafik perilaku kekerasan dalam rumah tangga itu selalu meningkat setiap tahunnya. Dan jalur untuk menjembatani keduanya itu diantaranya adalah dengan cara meningkatkan sosialisasi UndangUndang Penghapusan Kekerasan Dalam Rumah Tangga secara lebih intensif melalui berbagai metode dan media. Tulisan ini merupakan salah satu langkah konkret penyebarluasannya.

\section{Undang-Undang Penghapusan} Kekerasan Dalam Rumah Tangga / PKDRT telah disahkan pada tanggal 22 September 2004. Undang-Undang ini mengharamkan dan melarang keras perilaku KDRT terhadap orang yang ada dalam lingkup rumah tangga dengan cara kekerasan fisik, psikis, seksual, atau penelantaran (termasuk aspek ekonomi) dalam rumah tangga.
(Undang-Undang Nomor 23 Tahun 2004, Bab III, Pasal 5).

Maksud orang-orang yang berada dalam lingkup rumah tangga adalah suami, istri, anak, serta orang-orang yang mempunyai hubungan keluarga karena hubungan darah, perkawinan, persusuan, pengasuhan, perwalian, menetap dalam rumah serta orang yang bekerja membantu dan menetap dalam rumah tangga tersebut. (Undang-Undang Nomor 23 Tahun 2004, Bab I, Pasal 2, Ayat 1-2).

Potensi kemungkinan terjadinya kekerasan, khususnya terhadap perempuan dan anak dibagi menjadi tiga macam, yaitu di lingkungan keluarga atau domestic domain, di lingkungan masyarakat ataupublic domain, serta dalam skala besar dilakukan oleh negara atau state. (Kolibonso, Rita Serena; Oktober 2020).

Pembagian pokok bahasan kekerasan menjadi tiga bagian inilah yang kemudian dapat membuka tabir gelap tindak kekerasan, khususnya bentuk kekerasan dalam keluarga yang dikenal dengan sebutandomestic violence atau kekerasan dalam rumah tangga.

Kekerasan Dalam Rumah Tangga / KDRT atau Domestic violence itu bisa dilakukan dalam bentuk tindakan pemukulan (fisik), ancaman (psikis), pemaksaan hubungan intim (seksual), pengusiran dari rumah tanpa pemberian bekal yang cukup, larangan bekerja sambil dengan tidak memberi uang yang cukup ( factor ekonomi ini terma-suk ke dalam kategori penelantaran).

Bentuk kekerasan dalam rumah tangga itu bisa saja terjadi dari istri kepada suami, atau dari anak kepada orang tua, meskipun fakta yang sering 
terjadi adalah sebaliknya. Suami kepada istri, atau orang tua kepada anak.

\section{Konsep Dasar PKDRT}

Beberapa istilah umum dalam pembahasan konsep dasar PKDRT adalah: Kekerasan dalam rumah tangga, Penghapusan Kekerasan dalam rumah tangga, korban, perlindungan, perlindungan sementara, dan perintah perlindungan.

Berikut ini adalah penjelasan dari beberapa konsep dasar PKDRT (Undang-Undang Nomor 23 Tahun 2004, Bab I, Pasal 1, Ayat 1-6) tersebut:

1) Konsep dasar Kekerasan Dalam Rumah Tangga / KDRT adalah setiap perbuatan terhadap seseorang terutama perempuan, yang berakibat timbulnya kesengsaraan atau pende-ritaan secara fisik, seksual, psiko-logis, dan atau penelantaran rumah tangga termasuk ancaman untuk melakukan perbuatan, pemaksaan, atau perampasan kemerdekaan secara melawan hukum dalam lingkup rumah tangga.

2) Penghapusan Kekerasan dalam Rumah Tangga adalah jaminan yang diberikan oleh negara untuk mencegah terjadinya kekerasan dalam rumah tangga, menindak pelaku kekerasan dalam rumah tangga, dan melindungi korban kekerasan dalam rumah tangga.

3) Korban adalah orang yang mengalami kekerasan dan/atau ancaman kekerasan dalam lingkup rumah tangga.

4) Perlindungan adalah segala upaya yang ditujukan untuk memberikan rasa aman kepada korban yang dilakukan oleh pihak keluarga, advokat, lembaga sosial, kepolisian, kejak-saan, pengadilan, atau pihak lainnya baik sementara maupun berdasarkan penetapan pengadilan.

5) Perlindungan Sementara adalah perlindungan yang langsung diberikan oleh kepolisian dan/atau lembaga sosial atau pihak lain, sebelum dikeluarkannya penetapan perintah perlindungan dari pengadilan.

6) Perintah Perlindungan adalah penetapan yang dikeluarkan oleh Pengadilan untuk memberikan perlindung-an kepada korban.

Kekerasan dalam rumah tangga sebagaimana tersebut di atas itulah yang harus segera dihapus dan atau setidaknya diminimalkan keberadaannya dari setiap rumah tangga.

Penghapusan kekerasan dalam rumah tangga itu maksudnya adalah jaminan yang diberikan oleh negara untuk mencegah terjadinya kekerasan dalam rumah tangga, menindak pelaku kekerasan dalam rumah tangga, dan melindungi korban kekerasan dalam rumah tangga.

Korban kekerasan dalam rumah tangga itu bisa suami, istri, anak, atau pihak lain yang serumah. Akan tetapi umumnya yang menjadi korban adalah pihak yang lemah, seperti istri atau anak.

Perlindungan terhadap korban kekerasan dalam rumah tangga itu bisa dilakukan oleh siapa saja yang memiliki kemauan dan kemampuan dengan cara yang tepat dan prosedural.

Perlindungan sementara adalah perlindungan yang langsung dilakukan oleh siapa saja yang memiliki kemauan dan kemampuan dengan cara yang cepat dan tepat.

Perintah perlindungan adalah perintah pengadilan kepada negara un- 
tuk memberikan pengamanan kepada korban.

\section{Asas \& Tujuan UU-PKDRT}

Undang-Undang Penghapusan kekerasan dalam rumah tangga ini dijalankan sesuai dengan asas : Penghormatan hak asasi manusia, keadilan dan kesetaraan gender, nondiskriminasi, dan perlindungan korban.

Tujuannya adalah: Mencegah segala bentuk kekerasan dalam rumah tangga, melindungi korban kekerasan dalam rumah tangga, menin-dak pelaku kekerasan dalam rumah tangga, dan memelihara keutuhan rumah tangga yang harmonis dan sejahtera. (Undang-Undang Nomor 23 Tahun 2004, Bab II, Pasal 3 dan 4).

\section{Jenis-Jenis KDRT}

Ada empat jenis tindakan kekerasan dalam rumah tangga yaitu, kekerasan fisik, kekerasan psikis, kekerasan seksual, dan penelantaran rumah tangga, termasuk dalam penelantaran ini adalah lemahnya tanggung jawab dalam bidang ekonomi.

Penjelasan keempat jenis tindakan tersebut (Undang-Undang Nomor 23 Tahun 2004, Bab III, Pasal 5, 6, 7, 8 dan 9) adalah:

1) Kekerasan fisik yang dimaksud di sini adalah perbuatan yang mengakibatkan rasa sakit, jatuh sakit, atau luka berat.

2) Kekerasan psikis adalah perbuatan yang mengakibatkan ketakutan, hilangnya rasa percaya diri, hilangnya kemampuan untuk bertindak, rasa tidak berdaya, dan/atau pende-ritaan psikis berat pada seseorang.

3) Kekerasan seksual adalah: Pertama, pemaksaan hubungan seksual yang dilakukan terhadap orang yang menetap dalam lingkup rumah tangga tersebut. Meskipun terhadap pasangan sah nya sendiri, jika melakukan pemaksaan, maka bisa berkategori pada tindakan kekerasan. Kedua, pemaksaan hubungan seksual terhadap salah seorang dalam lingkup rumah tangganya dengan orang lain untuk tujuan komersial dan/ atau tujuan tertentu.

4) Penelantaran rumah tangga yang dimaksud di sini adalah: Pertama tindakan menelantarkan orang dalam lingkup rumah tangganya, padahal menurut hukum yang berlaku baginya atau karena persetujuan atau perjanjian ia wajib memberikan kehidupan, perawatan, atau pemeli-haraan kepada orang tersebut. Kedua, Penelantaran sebagaimana tersebut juga berlaku bagi setiap orang yang mengakibatkan keter-gantungan ekonomi dengan cara membatasi dan/atau melarang un-tuk bekerja yang layak di dalam atau di luar rumah sehingga korban ber-ada dibawah kendali orang tersebut.

\section{Grafik Korban Kekerasan terhadap Perempuan}

Menurut data yang berhasil dihimpun KOMNAS Perempuan, selama kurun waktu 12 tahun, sejak tahun 2008 - 2019 telah terdeteksi bahwa perilaku kekerasan terhadap perempuan me-ningkat sebanyak 792\% (hampir 800\%), atau mengalami peningkatan sebanyak hampir 8 kali lipat. Data tersebut ter-gambar dalam diagram berikut: 


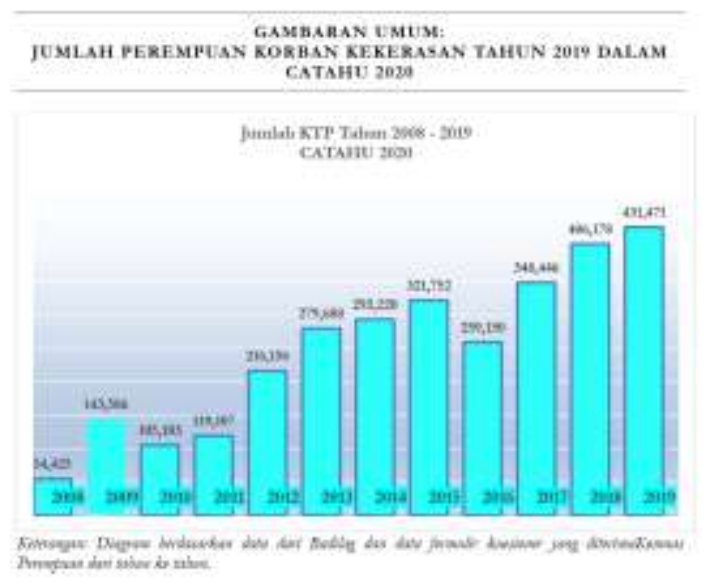

Pihak KOMNAS Perempuan meyakini bahwa data tersebut adalah fenomena gunung es, yang memiliki arti bahwa dalam situasi faktual / yang se-benarnya, kondisi tertentu perempuan Indonesia mengalami kehidupan yang kurang aman. Bila setiap tahun kecen-derungan kekerasan terhadap perem-puan konsisten mengalami pening-katan, maka hal ini menunjukkan lemahnya keamanan bagi perempuan. Fenomena ini jika dibiarkan terus, dapat menjadi perilaku yang membiasa, dan jika sudah membiasa maka bisa menjadi budaya yang berkembang secara umum dikalangan masyarakat. (KOMNAS Perempuan, 2020; 7).

\section{Bentuk Kekerasan terhadap Perempu- an}

Beberapa bentuk kekerasan terhadap perempuan menurut catatan KOMNAS Perempuan pada tahun tahun 2020 masih tetap tinggi. (KOMNAS Perempuan, 2020; 12). Kondisi itu sebagaimana tergambar dalam diagram berikut:

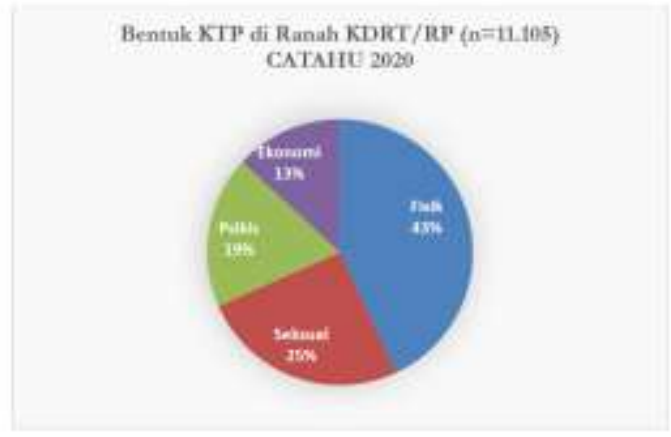

Data diatas menunjukkan bahwa bentuk kekerasan terhadap perempuan masih tetap tinggi. Bentuk kekerasan terbanyak adalah fisik (43\%), seksual sebanyak $(25 \%)$, psikis $19 \%$, dan ekonomi $13 \%$. Pola ini sama seperti pola di tahun sebelumnya, yaitu pada tahun 2008 - 2019.

\section{Faktor Penyebab Meningkatnya Peri- laku Kekerasan terhadap Perempuan}

Beberapa faktor yang menyebab-kan perilaku kekerasan terhadap pe-rempuan mengalami peningkatan terus, padahal UndangUndang Nomor 23 Tahun 2004 Tentang Penghapusan Kekerasan Dalam Rumah Tangga sudah diberlakukan (KOMNAS Perempuan, 2020; 9), adalah:

1) Asumsi bahwa KDRT adalah persoalan personal yang orang lain tidak perlu mencampurinya.

2) Asumsi bahwa kehidupan berumah tangga itu harus terlihat baik-baik saja.

3) Penanganan yang kurang tegas dari aparat penegak hukum.

4) Pemilihan vonis hukuman yang paling ringan.

5) Penyelesaian KDRT banyak melalui mediasi, atau jalan damai, baik di tingkat keluarga maupun kepolisian.

Hal ini menunjukkan bahwa pengetahuan dan pemahaman untuk menjaga dan membela diri masih 
kurang. Ditambah rasa malu yang tidak pada tempatnya terhadap keluarga, dan lingkungan jika diketahui secara umum. Sehingga akhirnya banyak yang memi-lih jalan damai meski harus dibayar dengan penderitaan yang panjang.

\section{Pencegahan KDRT}

Pemerintah bertanggung jawab dalam upaya pencegahan kekerasan dalam rumah tangga itu (UndangUndang Nomor 23 Tahun 2004, Bab III, Pasal 11, 12, 13, 14 dan 15) dengan cara:

1) Merumuskan kebijakan tentang penghapusan kekerasan dalam rumah tangga.

2) Menyelenggarakan komunikasi, informasi, dan edukasi tentang kekerasan dalam rumah tangga.

3) Menyelenggarakan advokasi dan sosialisasi tentang kekerasan dalam rumah tangga.

4) Menyelenggarakan pendidikan dan pelatihan sensitif gender dan isu kekerasan dalam rumah tangga serta menetapkan standar dan akreditasi pelayanan yang sensitif gender.

Pencegahan kekerasan dalam rumah tangga selain menjadi kewajiban pemerintah pusat, juga menjadi kewa-jiban pemerintah daerah untuk menye-lenggarakan pelayanan yang baik ter-hadap korban berupa:

1) Penyediaan ruang pelayanan khusus di kantor kepolisian,

2) Penyediaan aparat, tenaga kesehatan, pekerja sosial, dan pembimbing rohani,

3) Pembuatan dan pengembangan sistem dan mekanisme kerja sama program pelayanan yang melibatkan pihak yang mudah diakses oleh korban,

4) Memberikan perlindungan bagi pendamping, saksi, keluarga, dan teman korban.

Setiap orang dan organisasi, dari mana pun asalnya, dan kapan pun waktunya, jika mendengar, melihat, atau mengetahui terjadinya kekerasan dalam rumah tangga wajib melakukan upaya-upaya sesuai dengan batas kemampuannya untuk:

1) Mencegah berlangsungnya tindak pidana.

2) Memberikan perlindungan kepada korban.

3) Memberikan pertolongan darurat.

4) Membantu proses pengajuan permohonan penetapan perlindungan.

Tentu saja upaya pencegahan, pertolongan, atau perlindungan yang dilakukan itu harus dengan prosedur dan tata cara yang benar, dan dengan mengutamakan keselamatan diri sendiri terlebih dahulu. Misalnya jika melihat ada pelaku tindak kekerasan yang membawa senjata tajam, maka sebaiknya jangan langsung bertindak sendiri karena bisa membahayakan keselamatan dirinya, melainkan segera melapor kepada pihak keamanan atau pihak yang berwenang lainnya.

\section{Perlindungan Anak}

Setiap anak berhak atas kelangsungan hidup, tumbuh dan berkembang serta berhak atas perlindungan dari kekerasan dan diskriminasi sebagaimana diamanatkan dalam UndangUndang Dasar Negara Republik Indonesia Tahun 1945.

Seorang anak adalah tunas, potensi, dan generasi muda penerus cita-cita perjuangan bangsa memiliki peran strategis, ciri, dan sifat khusus 
sehingga wajib dilindungi dari segala bentuk perlakuan tidak manusiawi yang mengakibatkan terjadinya pelanggaran hak asasi manusia.

Dalam rangka meningkatkan perlindungan terhadap anak perlu dilakukan penyesuaian terhadap beberapa ketentuan dalam Undang-Undang Nomor 23 Tahun 2002 tentang Perlindungan Anak, maka pihak pemerintah dan legislative melakukan penyempur-naan peraturan dengan mengeluarkan Undang-Undang Republik Indonesia Nomor 35 Tahun 2014 Tentang Perubahan Atas UndangUndang Republik Indonesia Nomor 23 Tahun 2002 Tentang Perlindungan Anak.

\section{Konsep Dasar Perlindungan Anak}

Pengertian anak adalah seseorang yang belum berusia 18 (delapan belas) tahun, termasuk anak yang masih dalam kandungan. Anak seusia tersebut diasumsikan masih belum bisa mandiri dalam banyak hal, karenanya harus dibina, dididik, dan dilindungi sebaik dan semaksimal mungkin.

Untuk dapat melakukan perlindungan kepada seorang anak dengan seoptimal mungkin, siapa dan bagaimana, maka dibutuhkan pengertian konsep dasar perlindungan anak yang mudah dipahami, dan perlu disebarluaskan kepada seluruh rakyat Indonesia. Adapun konsep dasar perlin-dungan anak sebagaimana disebutkan dalam undang-undang adalah sebagai berikut: Perlindungan Anak adalah segala kegiatan untuk menjamin dan me-lindungi anak dan hak-haknya agar dapat hidup, tumbuh, berkembang, dan berpartisipasi secara optimal sesuai de-ngan harkat dan martabat kemanusiaan, serta mendapat perlindungan dari kekerasan dan diskriminasi.

(Undang-Undang Republik Indonesia Nomor 35 Tahun 2014 Tentang Perubahan Atas Undang-Undang Republik Indonesia Nomor 23 Tahun 2002 Tentang Perlindungan Anak, Pasal I, Ayat 1 - 2).

\section{Cara Perlindungan Anak}

Pihak-pihak yang berkewajiban melakukan perlindungan terhadap anak adalah: Negara, pemerintah, Pemerintah Daerah, Masyarakat, Keluarga, dan orang tua atau Wali berkewajiban dan bertanggung jawab terhadap penyelenggaraan Perlindungan Anak. Adapun cara yang dapat dilakukan untuk melindungi anak secara umum adalah dengan memberinya kesempatan.

(Undang-Undang Republik Indonesia Nomor 35 Tahun 2014 Tentang Perubahan Atas Undang-Undang Republik Indonesia Nomor 23 Tahun 2002 Tentang Perlindungan Anak, Pasal I, Ayat 1 - 20) untuk:

1) Beribadah menurut agamanya, berpikir, dan berekspresi sesuai dengan tingkat kecerdasan dan usianya dalam bimbingan orang tua atau Wali.

2) Memperoleh pendidikan dan pengajaran dalam rangka pengembangan pribadinya dan tingkat kecerdasannya sesuai dengan minat dan bakat.

3) Mendapatkan perlindungan di satuan pendidikan dari kejahatan seksu-al dan Kekerasan yang dilakukan oleh pendidik, tenaga kependidikan, sesama peserta didik, dan/atau pihak lain.

4) Memperoleh pendidikan luar biasa bagi anak penyandang cacat, dan 
anak yang memiliki keunggulan berhak mendapatkan pendidikan khusus.

5) Memperoleh rehabilitasi, bantuan sosial, dan pemeliharaan taraf kesejahteraan sosial, bagi anak penyandang disabilitas.

6) Diasuh oleh orang tuanya sendiri, kecuali jika ada alasan dan/atau aturan hukum yang sah menunjukkan bahwa pemisahan itu adalah demi kepentingan terbaik bagi Anak dan merupakan pertimbangan ter-akhir. Dalam hal terjadi pemisahan sebagaimana disebutkan, maka anak tetap berhak untuk:

a) Bertemu langsung dan berhubungan pribadi secara tetap dengan kedua orang tuanya.

b) Mendapatkan pengasuhan, pemeliharaan, pendidikan dan perlindungan untuk proses tumbuh kembang dari kedua orang tua-nya sesuai dengan kemampuan, bakat, dan minatnya.

c) Memperoleh pembiayaan hidup dari kedua orang tuanya.

d) Memperoleh Hak Anak lainnya.

7) Memperoleh perlindungan dari:

a) Penyalahgunaan dalam kegiatan politik.

b) Pelibatan dalam sengketa bersen jata.

c) Pelibatan dalam kerusuhan social.

d) Pelibatan dalam peristiwa yang mengandung unsur Kekerasan.

e) Pelibatan dalam peperangan, dan

f) Kejahatan seksual.

\section{Simpulan}

Undang-Undang tentang Penghapusan Kekerasan Dalam Rumah
Tangga / UU-PKDRT ini, mengatur pencegahan dan perlindungan serta pemulihan terhadap korban kekerasan dalam rumah tangga, juga secara spesifik membahas tentang kekerasan yang terjadi dalam rumah tangga dengan unsur-unsur tindak pidana yang berbeda dengan tindak pidana penganiayaan yang diatur dalam KUHP.

Undang-Undang ini juga menga-tur kewajiban bagi aparat penegak hu-kum, tenaga kesehatan, pekerja sosial, relawan pendamping, atau pembim-bing rohani untuk melindungi korban agar mereka lebih sensitif dan responsif terhadap kepentingan rumah tangga yang sejak awal diarahkan pada keutuhan, kerukunan, dan keharmo-nisan rumah tangga.

Sejak diberlakukannya UUPKDRT ini pada tahun 2004, ternyata data yang ada menunjukkan bahwa perilaku kekerasan dalam rumah tangga terus meningkat dengan korban utamanya adalah perempuan dan anak.

Minimnya pengetahuan dan pemahaman, rasa malu yang tidak pada tempatnya menyebabkan jalan akhir yang dipilih adalah berdamai meskipun terpaksa.

\section{Saran}

Saran yang dapat penulis sampaikan adalah:

\section{a. Bagi Pihak yang Lemah}

Memperbanyak bacaan dan memperkuat pemahaman terutama mengenai penyebab, pencegahan, dan solusi perilaku kekerasan dalam rumah tangga.

\section{b. Bagi Pihak yang Kuat}

Meningkatkan kesadaran bahwa di dunia ini ada hukum negara, dan di 
akhirat itu ada balasan yang setimpal.

\section{c. Bagi Regulator}

Menyebar-luaskan berbagai perundangan dan peraturan terkait dengan kekerasan, terutama kekerasan dalam rumah tangga dengan lebih intensif.

\section{d. Bagi Masyarakat}

Meningkatkan kepedulian kepada lingkungan sekitar khususnya mengenai kekerasan dalam rumah tangga, dengan cara melaporkannya pada ketua RT / Rukun Tetangga setempat.

\section{REFERENSI}

\section{A. Referensi Regulasi Negara}

Undang-Undang Republik Indonesia Nomor 23 Tahun 2002, Tentang Perlindungan Anak, Softcopy.

Undang-Undang Republik Indonesia Nomor 35 Tahun 2014 Tentang Perubahan Atas Undang-Undang Nomor 23 Tahun 2002, Tentang Perlindungan Anak, Softcopy.

Undang-Undang Republik Indonesia Nomor 17 Tahun 2016 Tentang Penetapan Peraturan Pemerintah Pengganti Undang-Undang Nomor 1 Tahun 2016 Tentang Perubahan Kedua Atas Undang-Undang Nomor 23 Tahun 2002, Tentang Perlindungan Anak Menjadi Undang-Undang, Softcopy.

Peraturan Pemerintah Pengganti Undang-Undang Republik Indonesia Nomor 1 Tahun 2016 Tentang Perubahan Kedua Atas Undang-
Undang Nomor 23 Tahun 2002 Tentang Perlindungan Anak, Softcopy.

Undang-Undang Republik Indonesia Nomor 23 Tahun 2004 Tentang Penghapusan Kekerasan Dalam Rumah Tangga, Softcopy.

\section{B. Referensi Buku dan Kitab}

KOMNAS Perempuan (2020), Catatan Kekerasan Tahunan Terhadap Perempuan, Jakarta, Softcopy.

Pusat Bahasa Jakarta (2008), Kamus Bahasa Indonesia, Jakarta, Pusat Bahasa Departemen Pendidikan Nasional, Softcopy.

Sugema Sony, Digitalquran, ver. 3.1, tp, 2003-2004, softcopy,

http://www.geocities.com/sonysuge $\underline{\text { ma2000 }}$

\section{Referensi Internet}

Kolibonso, Rita Serena; Oktober 2020, https://buletinhukum.com/penegaka n-hukum-kejahatan-kekerasan-dalamrumah-tangga/,

Jogloabang; Oktober 2020, https://www.jogloabang.com/pustaka Luu-23-2004-penghapusan-kdrt,

Kemenpora 1; Oktober 2020,

https://www.kemenpppa.go.id/index. $\mathrm{php} / \mathrm{page} / \mathrm{read} / 31 / 1668 /$ kdrt-bukanlagi-ranah-privat-segera-laporkan-jikaanda-menemukan-kasusnya,

Kemenpora 2; Oktober 2020, 


\section{Wawasan}

Jurnal Balai Diklat Keagamaan Jakarta PISSN 2548-9232; EISSN .....

Volume 1 Nomor 1 Tahun 2020:60-71

https://www.kemenpppa.go.id/index.

$\mathrm{php} / \mathrm{page} / \mathrm{read} / 29 / 1833 /$ rumah-

tangga-tangguh-cegah-kdrt, 